УДК 347.4

DOI https://doi.org/10.51989/NUL.2021.5.2

\title{
ТЕМПОРАЛЬНІ ЧИННИКИ ЗДІЙСНЕННЯ СУБ'ЄКТИВНОГО ЦИВІЛЬНОГО ПРАВА. ІСТОРИЧНИЙ АСПЕКТ
}

\section{Гуйван Петро Дмитрович,}

кандидат юридичних наук, заслужений юрист України, професор

Полтавського інституту бізнесу

Стаття присвячена науковому дослідженню актуального питання про часові виміри здійснення регулятивного цивільного права та його співвідношення із тривалістю права на захист у разі порушення, зокрема і шляхом пред'явлення позовного домагання. Вивчено історичний поступ науки щодо інтерпретацій суспільного сприйняття періоду їхнього існування. Установлено, що первинно як наукова думка, так і відповідне законодавство грунтувалися на концепції єдиної давності як явищі, що руйнує навіть безспірне право. Уважалося, що погашення суб'єктивного права давністю є умовою, що супроводжує саме його виникнення. Проте розвиток цивілістичної науки, ґрунтуючись на відмінностях як правової природи, так і окремого юридичного регулювання інститутів набувальної та позовної давностей, привів до усвідомлення необхідності роздільного правового регулювання цих двох інститутів. Це відобразилося на науковому сприйнятті взаємозв'язків між виникненням та припиненням періоду існування позовного домагання та тривалістю самого суб'єктивного права, що зазнало порушення. Тривалий час у науці обстоювалася теза про те, що в момент порушення суб'єктивне право трансформується у право на позов, існує у такому стані упродовж встановленого строку, а потім разом із закінченням позовної давності припиняється. Однак еволюція чинного законодавства зумовила зміну концепції і цього разу, адже неможливо стало пояснити правило про належність виконання задавненого зобовязання після спливу позовної давності (частина 1 статті 267 Цивільного кодексу України). Тож нині найбільш прийнятною є теза про те, що позовною давністю погашається лише право на позов, а не саме суб'єктивне матеріальне право, тобто про продовження існування після збігу давнісного строку позбавленого судового захисту суб'єктивного матеріального права. Добровільне виконання в цей час обов'язку боржником є належним, і останній не має права вимагати повернення виконаного. Але для ефективності даної правової побудови обов'язково варто додати, що продовжує існувати не порушене регулятивне право, а охоронне, яке втратило свою примусову здатність до реалізації. Добровільне здійснення саме цього права буде належним.

Ключові слова: позовна давність, задавнений обов'язок, строк.

\section{Guyvan Petro. Temporal factors of exercise of subjective civil law. Historical aspect}

The article is devoted to the research of the topical issue of the temporal dimensions of the exercise of regulatory civil law and its relationship with the duration of the right to protection in case of violation, including by filing a claim. The historical progress of science on interpretations of public perception of the period of their existence is studied. It is established that initially, both scientific opinion and relevant legislation were based on the concept of a single statute of limitations, as a phenomenon that destroys even the undisputed right. It was believed that the expiration of a subjective right by prescription is a condition that accompanies its emergence. However, the further development of civil science, based on the differences of both legal nature and separate legal regulation of acquisitive and statute of limitations, has led to the realization of the need for separate legal regulation of these two institutions. This is reflected in the scientific perception of the relationship between the occurrence and termination of the period of existence of the claim and the duration of the subjective right itself, which received the violation. For a long time, science has argued that at the time of violation, the subjective right is transformed into a right to sue, and exists in this state for a specified period, and then, with the expiration of the statute of limitations, is terminated. However, the evolution of current legislation has led to a change in the concept and this time, because it was impossible to explain the rule of due performance of a long-standing obligation after the expiration of the statute 
of limitations (Part 1 of Article 267 CCU). Therefore, currently the most acceptable thesis is that the statute of limitations extinguishes only the right to sue, and not the subjective substantive right itself, ie the continuation of the subjective substantive right deprived of judicial protection after the expiration of the statute of limitations. Voluntary performance by the debtor at this time is due, and the debtor is not entitled to demand the return of the performance. But for the effectiveness of this legal construction, it must be added that it continues to exist not violated regulatory law, but protection, which has lost its coercive ability to implement. Therefore, the voluntary exercise of this right will be appropriate.

Key words: statute of limitations, statute of limitations, term.

Нині актуальною $є$ проблематика своєчасного здійснення суб'єктивного права. Зокрема, важливим $є$ темпоральне співвідношення права на позов і регулятивного права. Результативність застосування тих чи інших правових норм, що регулюють перебіг деяких строків, на жаль, не $\epsilon$ головним критерієм встановлення сфери застосування правового інституту. Отже, мусимо здійснити наукове дослідження цієї проблематики, адже серйозність питання про можливість існування регулятивного матеріального права зі спливом позовної давності потребує пильної уваги. Потребує аналізу питання про строки існування самого суб'єктивного права, на судовий захист якого претендує кредитор, та співвідношення цього темпорального чинника із часом існування охоронного права, спрямованого на захист. Якщо пристати до популярної колись тези, що із закінченням перебігу позовної давності припиняється регулятивне право, то в такому разі можна було 6 вести мову про припинення права на судовий захист у зв'язку із припиненням предмету захисту. До речі, вказана підстава була б додатковою щодо часового регулювання захисту цивільного права, адже законодавство передусім пов'язує відмову в реалізації права на позов зі збігом давнісного строку. Варто з'ясувати, чи припиняється після спливу давнісного строку охоронне право носія на захист порушеного регулятивного права. Якщо ні, то яке саме право припиняється і чи припиняється взагалі?

Дамо нині відповіді на поставлені запитання. У літературі вони досить жваво обговорювалися, правовий стан наукового аналізу яскраво свідчить про еволюційний розвиток і ефективність вказаних досліджень. Проаналізуємо історичний поступ відповідних доктринальних напрацювань. У другій половині XIX - на початку XX ст. в цивілістичних працях та чинному на той час законодавстві панувала теза, згідно з якою нездійснення суб'єктивного цивільного права протягом досить тривалого часу фактично означає припинення інтересу до нього з боку правоволодільця. Сила давності розумілася якраз таким чином, що вона руйнує безспірне право. Уважалося, що погашення суб'єктивного права давністю $є$ умовою, що супроводжує саме його виникнення. Бездіяльне право визнавалося життєздатним лише до певного моменту, а давність - межею життєздатності бездіяльного права, що давно не заявляло про себе [1, с. 8]. Такий досить виважений підхід міг би мати перспективи та доцільність подальшого ефективного розвитку, якби він стосувався строкових зобов'язальних прав та кореспондуючих їм обов'язків учасників відносин. Насправді, тогочасні дослідники в основному поширювали вказану наукову розробку на відносини власності. Отже, постулювалася втрата цього суб'єктивного права внаслідок його тривалого (за невизначеності суспільно бажаного) строку [2, с. 221], що не виглядало досить переконливим.

Більшої виваженості дана концепція набувала в дослідженні ситуацій, коли власник майна з якихось не залежних від своєї волі причин втрачав своє майно. Тут уже бездіяльність останнього мала кваліфікуюче значення: оскільки давністю вважався строк, протягом якого неволодіючий власник втрачав своє матеріальне суб'єктивне право власності, то логічно було припустити, що впродовж даного періоду нетитульний володілець набуває його. Тобто давність як єдина категорія розглядалася явищем, протягом перебігу якого відбувається або набуття певного права, або його погашення. Уважалося, що давність, протягом якої набувалося суб'єктивне матеріальне право (набувальна), та давність, сплив якої призводить до втрати права (згашувальна), є еле- 
ментами того самого правового інституту [3, с. 2-3]. Наступний розвиток цивілістичної науки, ґрунтуючись на відмінностях як правової природи, так і окремого юридичного регулювання інститутів набувальної та позовної давностей [4, с. 15-16] привів до усвідомлення необхідності роздільного правового регулювання цих двох інститутів.

Позовна давність поступово набула правового значення, яке має і зараз, - це строк, протягом якого особа може реалізувати належне їй матеріальне право на отримання судового захисту порушеного цивільного права чи інтересу шляхом пред'явлення в належному порядку нею чи іншою уповноваженої особою позову до суду [5, с. 81]. Вказана зміна оцінки юридичної сутності зазначеного строку не могла не відобразитися на науковому сприйнятті взаємозв'язків між виникненням та припиненням періоду існування позовного домагання та тривалістю самого суб'єктивного права, що порушено. Питання про існування суб'єктивного права поза межами позовної давності завжди було актуальним, як показує історичний аналіз його дослідження, непростим. Звісно, цивілістичні дослідження вказаних зв'язків відбувалися в межах нин критикованої нами, але на той час єдиної загальноприйнятної концепції, за якою повноваження на позов уважалося елементом самого суб'єктивного права, набувало здатності до примусової реалізації після правопорушення. У межах даної концепції науковий аналіз щодо тривалості матеріального права з огляду на закінчення строку дії одного з його невід'ємних елементів - домагання - цілком логічно привів до двох можливих висновків.

Перший полягав у тому, що суб'єктивне право, не наділене здатністю до примусового захисту, існувати не може. Тобто внаслідок спливу строку давності припиняється не тільки право на судовий захист, а й саме охоронюване матеріальне право, незалежно від того, збігається воно за змістом із позовною вимогою чи ні. Тривалий час твердження, що зі спливом позовної давності гаситься і саме суб'єктивне право, панувало серед науковців [6, с. 172]. Зокрема, у літературі вказувалося, що вимоги з договорів після спливу давності знищуються, зобов'язана особа звільняється від обов'язку, саме право припиняється, а його зміст зникає $[7$, с. 399, 476-480]. Фактично, з даного погляду зі спливом позовної давності відбувається зовнішній удар по життєво важливій функції права - його здатності до примусового виконання зобов'язання. А існування суб'єктивного права без охоронної властивості неможливе. Отже, сплив позовної давності знищує суб'єктивне право ззовні, тоді як присічний строк припиняє існування матеріального права зсередини [8, с. 14]. Вказаний юридичний підхід обґрунтовувався із прагматичного погляду: адже навіщо потрібне суб'єктивне право, що, перебуваючи в порушеному стані, не може бути примусово захищене? Тож, з урахуванням того факту, що за коментованою теорією в момент порушення суб'єктивне право трансформується у право на позов, його припинення із закінченням позовної давності виглядає закономірним.

Прихильниками даної теорії в різні періоди були такі вчені, як: Г.Ф. Шершеневич, В.І. Синайський, М.М. Агарков, О.C. Іоффе й інші. Вони обстоювали позицію, за якою погашення можливості примусового захисту порушеного права (припинення матеріального права на позов) спричиняє такий же наслідок для самого охоронюваного матеріального права. Тобто непред'явлення позову до спливу вказаного в законі строку призводить до погашення, втрати порушеного права. Кредитор уже не може нічого вимагати від боржника, а боржник не зобов'язаний нічого виконувати. На такій же позиції, згідно з якою сплив давнісного строку призводить до припинення як самого порушеного права, так і права на позов (бо останнє розумілося як порушене право, здатне до примусового здійснення), перебував і М. Ринг [9, с. 84].

Інші дослідники, які теж уважали матеріальне право на позов особливим станом самого суб'єктивного права, усе ж вказували, що зі спливом давнісного строку припиняється лише право на захист, саме ж матеріальне право продовжує існувати. Так, К.Н. Анненков вказував, що положення закону про знищення позову та припинення справи необхідно розуміти як закінчення дії права на позов, і аж 
ніяк не поширювати його на існування охоронюваного цивільного правовідношення [10, с. 476-477]. Подібної думки дотримувалися також С.М. Абрамов, М.Я. Лапиров-Скобло, С.І. Вильнянський, І.Б. Новицький, Б.Б. Черепахін та інші. Вони підкреслюють, що закінчення перебігу давнісного строку перешкоджає можливій примусовій реалізації права в судовому порядку, але матеріальне право продовжує існувати і після спливу давності. Унаслідок цього право стає дещо дефектним, урізаним, але ніяк не припиненим. Правило, яке нині закріплене в ч. 2 ст. 20 Цивільного кодексу (далі ЦК) України, варто тлумачити саме таким чином, а слово «нездійснення» варто розуміти не як бездіяльність протягом певного часу, а як результат, який виявився після закінчення строку для судового захисту. Окремі прихильники даного наукового підходу, щоби пом'ягшити загальне несприйняття існування так званого натурального (позбавленого примусового захисту) зобов'язання, яке продовжує існувати після спливу позовної давності, вказували на те, що воно по суті не $є$ зобов'язанням: із закінченням дії позовного домагання відносини переходять з області юридичних до сфери фактичних, це і зумовлює спеціальне соціально навантажене розуміння поняття «обов'язок» [11, с. 7-8].

Отже, як ми пересвідчилися, питання не було очевидним, між прихильниками вказаних підходів довгий час тривала жвава дискусія (ця дискусія продовжується в цивілістиці і зараз, проте вона перенесена в дещо іншу площину з урахуванням зміни концептуального базису). У XX ст. концепція про погашення матеріального права після збігу давнісного строку почала піддаватися критиці. Особливо це проявилося в 60-70-х рр.: з'явилися численні наукові публікації, у яких обстоювалася теза щодо відсутності прямого впливу закінчення перебігу давнісного строку на час існування самого суб'єктивного права [12, с. 189]. Не дивно, що зрештою більш прогресивною була фактично визнана правова позиція, яка визначала, що право продовжує існувати після втрати ним своєї захисної примусової здатності, хоча воно стає менш дієвим та захищеним [13, с. 375-377]. Після того, як дав- нісний строк минув, регулятивне право не припиняється, дія його продовжується у стані jus nuddum - «голого права», позбавленого охоронної здатності. Проте така позиція обґрунтовувалася не зміною підходу до аналізу внутрішньої сутності досліджуваних відносин, а тим, що загальнотеоретичні висновки про припинення суб'єктивного права з погашенням його примусової властивості суперечили чинному законодавству. Ідеться про нормативне правило, яке вказує на можливість заперечення правоволодільця проти зворотної вимоги виконаного після спливу давнісного строку, яке відтворено у ст. 47 ЦК РСФСР 1922 р., СТ. 82 ЦК УРСР 1963 р., нині міститься в ч. 1 ст. 267 ЦК України.

Як бачимо, далася взнаки давня хвороба нашої юридичної науки: не доктринальна думка дає поштовх для вдосконалення чинного законодавства, а радше навпаки, чинні правові норми змушують учених шукати їм наукового обґрунтування. Частіше за все такі пошуки призводять до штучної підгонки тих, що реально існують, правовідносин під правову надбудову, спотворюють їхню природу та надають їм рис ненормального розвитку. Зрештою, через певний час такі регулятивні механізми демонструють свою недієвість та скасовуються, змушують учених знаходити нове обґрунтування для взаємин, що реально існують. Проте в нашому разі маємо щасливий виняток з описаного вище правила: запровадження в цивільному законодавстві положення про належність виконання обов'язку після спливу позовної давності підштовхнуло вчених-цивілістів до пошуків реального та конкретного його наповнення. Вказане положення цивільного законодавства на перший погляд зняло наявні розбіжності щодо оцінки співвідношення тривалості суб'єктивного права із закінченням давнісного перебігу за вимогами стосовно його судового захисту. Адже, якщо погодитися з тезою про припинення суб'єктивного права зі спливом позовної давності, неодмінно постає питання про підставність добровільного виконання боржником обов'язку після закінчення давнісного строку. Бо закон веде мову саме про обов'язок, тож, коли виходити з положень теорії зобов'язань, то варто визнати, що єдиною підставою для 
існування певного обов'язку $€$ наявність правовідношення та суб'єктивного права, що кореспондує вказаному обов'язку.

Зазначене нормативне правило, здавалося 6, ще раз побічно підтвердило той факт, що після збігу давнісного строку саме матеріальне право не припиняється: у правовій нормі йдеться про виконання, а виконати можна лише наявне зобов'язання. Отже, цивільно-правове зобов'язання продовжує існувати і поза межами давнісних строків, бо інакше, якби суб'єктивне право внаслідок закінчення часу існування домагання погасилося, виконання боржника становило собою дію без належної правової підстави і підлягало поверненню через пряму вказівку відповідної статті Цивільного кодексу. Отже, зобов'язання продовжує існувати після позовної давності, хоча і втратило свою позовну силу. Прихильники іншої наукової доктрини, згідно з якою закінчення давнісного строку призводить до припинення дії суб'єктивного цивільного права особи [14, с. 267; 15, с. 122-123], не склали зброї. Звісно, поява законодавчого припису про належність виконання обов'язку, попри навіть збіг позовної давності, ускладнила дослідження, однак основні концептуальні положення не зазнали змін: не можна уявити собі існування суб'єктивного права, яке не може бути захищене в судовому порядку. Отже, автори даної теорії виходили з потреби встановлення чітких меж існування суб'єктивного права, забезпеченого обов'язковим своїм атрибутом - позовною властивістю. I саме кінцевим терміном строку існування такого цивільного права було обрано момент спливу давнісного строку.

У межах цієї доктрини виникали різні питання щодо сутності коментованих явищ, які не просто було узгодити з нормативним правилом: з одного боку, продовжувала викликати сумнів доцільність подальшого існування матеріального права, що втратило примусову властивість, з іншого - важко було пояснити дієвість погашеного суб'єктивного права в разі добровільного виконання обов'язку боржником чи відновлення давнісного строку. Адже якщо зобов'язання вже не існує, виконання варто визнати безпідставним, а все виконане мало 6 повер- нутися до виконавця. Зрештою, якщо вважати задавнене суб'єктивне право припиненим, виникає логічне питання: про захист якого матеріального права в суді йтиметься в разі пред'явлення позову, адже згідно із законодавством правозастосовний орган мусить прийняти до розгляду позовну заяву незалежно від спливу позовної давності.

Хай там як, а прихильники цієї правової теорії підійшли до аналізу традиційно для радянських часів: не ставили під сумнів доцільність та сутнісну обґрунтованість існування правила, викладеного в нинішній редакції ч. 1 ст. 267 ЦК України, вони намагалися знайти наукове пояснення виконанню обов'язку (адже закон веде мову саме про виконання зобов'язання), який, на їхнє переконанням, припинився. Були напрацьовані декілька різних теорій. Так, О.С. Іоффе розробив теоретичну побудову, за якою з огляду на те, що добровільне виконання обов'язку після спливу позовного строку певним періодом не обмежується, здійснення такого виконання означатиме, що давнісний строк фактично не сплив, а відповідне суб'єктивне право продовжує перебувати в законному стані. На думку вченого, подальше добровільне виконання $\epsilon$ юридичним фактом, у разі появи якого паралізується погашаюча дія позовної давності, тож суб'єктивне право за таких обставин варто вважати наявним і таким, що ніколи не припинялося [14, с. 266-267]. Д.М. Генкін також уважав, що цивільне право не може існувати, не спираючись на примусову санкцію, тож вказував, що суб'єктивне право припиняється зі збігом позовної давності. щоби пояснити подальшу дієвість відповідного суб'єктивного права й обов'язку в разі добровільного виконання, учений постулював, що елементи примусу виявляються не лише в позовному захисті права, а й у встановленій законодавчо можливості заперечувати проти пред'явленого позову. Він обгрунтовував визначену цивільним законом неможливість повернення виконаного боржником після спливу давності обов'язку [16, с. 255].

М.П. Рингом та І.М. Болотниковим була розроблена ще одна юридична конструкція, покликана сумістити теорію про погашення давністю суб'єктивного 
права з коментованою нормою закону. у ній підкреслювалося, що виконання простроченого обов'язку є підставою для нового правовідношення через пряму вказівку закону. Змістом нового відношення $\epsilon$ те, що уповноважений набуває право на виконане, а зобов'язана особа, відповідно, не може вимагати його повернення. Нове зобов'язання, будучи прямо встановленим ч. 1 ст. 267 ЦК, виникає за приписом закону з нового здійснення позитивних дій, за змістом збігається з тим обов'язком, який припинився після спливу давнісного строку. Сама вольова дія боржника після закінчення позовної давності $\epsilon$ умовою і підставою правових наслідків, у результаті чого у кредитора відновлюється суб'єктивне право [11, с. 8]. Тому засобом захисту вже нового права є заперечення пред'явленій вимозі. Тож, попри те, що суб'єктивне право після пропуску позовної давності $€$ де-факто втраченим, за його носієм зберігається повноваження на набуття цього права знову внаслідок позитивної дії іншої особи $[17$, с. 12]. Нарешті, О.О. Красавчиков обґрунтовував продовження існування суб'єктивного права передбаченою законом можливістю його захисту після закінчення позовної давності (тобто в разі відновлення позовної давності) [18, с. 288]. Дану позицію, за якою відновлення судом позовної давності $\epsilon$ фактично відновленням суб'єктивного регулятивного права, що свого часу припинилося, підтримували й інші науковці.

У літературі вже вказувалося на умовність та штучність наведених правових конструкцій, які не витримують перевірки практикою [19, с. 197-198]. Річ у тому, що важливою ознакою будь-якого суб'єктивного права як для носія, так і для суспільства $€$ його визначеність на кожен момент існування. Якщо ж повернутися до зазначених вище конструкцій, то з їхнього змісту невідомо, чи існує суб'єктивне право протягом часу від закінчення давнісного строку до моменту добровільного виконання обов'язку боржником. А такий період може бути досить тривалим. Не можна визнати надто вдалими такі, наприклад, пояснення належності виконання задавненого обов'язку, що право кредитором зі спливом давності втрачається, але після виконання боржником набувається знову через пряму вказівку про це в законі чи факт отримання майна [20, с. 102]. Окрім того, хибною є теза, згідно з якою підставою для виникнення нового правовідношення $€$ сам факт виконання, що відбулося після спливу давнісного строку [14, с. 267]. Вона не може бути прийнятною, 60 не узгоджується із загальними засадами зобов'язально-правової теорії. Якщо вважати виконання юридичним фактом, що породжує правовідношення, то, звісно, варто встановити обсяг прав та обов'язків такого правовідношення. Нині ж питання про те, яке ж право виникає і які юридичні наслідки невиконання відповідного обов'язку, залишаються без відповіді. Також незрозуміло, звідки виникає нове право, має бути правова підстава для нього. Закон чітко веде мову про виконання обов'язку, він не передбачає такої правової передумови для виникнення зобов'язання, як виконання, безпідставне і поготів. Перелік підстав для припинення зобов'язань, передбачений гл. 50 ЦК України, має вичерпний характер і не містить такої, як сплив позовної давності.

Отже, думка про те, що суб'єктивне право після закінчення перебігу позовної давності припиняється, а після відновлення давності воно з'являється знову, заслуговує критичної оцінки. Якщо їі дотримуватися, то варто визнати, що в період від закінчення позовної давності до моменту її відновлення судом матеріальне право не існувало. У такому разі боржник не має жодних підстав для добровільного виконання зобов'язання, а якщо воно буде в цей період здійснене, то таке виконання підлягає поверненню як безпідставне. А це суперечить правилу ч. 1 ст. 267 ЦК. Окрім того, коли навіть вважати закінчення позовної давності підставою для припинення матеріального права, то для його нового виникнення таких підстав взагалі немає. Не можна, звичайно, уважати такою підставою рішення суду про захист права, що припинилося.

Зазначені пояснення випливають з об'єктивного стану відносин у коментованій царині та дозволяють цілком відкинути потребу в конструюванні чергових підстав для нового правовідношення після спливу позовної давності. Тож, з урахуванням сказаного, цивілістична думка в основному 
прийшла до переконання, що правовідношення продовжує існувати незалежно від перебігу позовної давності. Саме тому зараз більшість учених не підтримують думку про поновлення матеріального права в разі відновлення позовної давності. Більш прийнятною $€$ теза про те, що позовною давністю погашається лиш право на позов, а не саме суб'єктивне матеріальне право, тобто про продовження існування після збігу давнісного строку позбавленого судового захисту суб'єктивного матеріального права. Отже, після закінчення давнісного перебігу захист порушеного суб'єктивного права в судовому порядку не може бути здійснено. Проте саме охоронюване право зі спливом давності не припиняється, а продовжує існувати, будучи позбавлене засобів примусового захисту, навіть більше, добровільне виконання в цей час обов'язку боржником $€$ належним, останній не має права вимагати повернення виконаного. Єдине, що обовязково варто додати, продовжує існувати не порушене регулятивне право, а охоронне, яке втратило свою примусову здатність до реалізації. Отже, добровільне здійснення саме цього права буде належним.

\section{ЛITEPATУPA:}

1. Боровиковский А.Л. Отчет судьи. Санкт-Петербург, 1892. Т. 2. 260 с.

2. Шершеневич Г.Ф. Учебник русского гражданского права / ред.: В.А. Краснокутский. 11-е изд. Москва : Бр. Башмаковы, 1914. Т. 1. 499 с.

3. Guyvan P. Theoretische Fragen der Ersitzung und deren Verhältnis zu den Klagefristen. Recht der Osteuropäischen Staaten (ReOS). 2016. № 1. S. 1-12.

4. Калачов Н.В. О давности по русскому гражданскому праву. Юридический вестник. Москва, 1867. Кн. 1 (Июль). С. 1-18.

5. Гуйван П.Д. Позовна давність : монографія. Харків : Право, 2012. 448 с.

6. Гурвич М.А. Право на иск / отв. ред. : А.Ф. Клейнман. Москва ; Ленинград : Изд-во АН СССР, 1949. 216 C.

7. Энгельман И.Е. О давности по русскому гражданскому праву. Историко-догматическое исследование. Москва : Статут, 2003. 511 с.

8. Гурвич М.А. Пресекательные сроки в советском гражданском праве. Москва : ВЮзИ, 1961. 80 c.

9. Ринг М. Действие исковой давности в советском гражданском праве. Советское государство и право. 1953. № 8. С. 78-85.

10. Анненков К.Н. Система русского гражданского права: Права обязательственные. Санкт-Петербург : Тип. М.М. Стасюлевича, 1901. Т. 3. 495 с.

11. Болотников И.М. Проблемы исковой давности в советском гражданском праве : автореф. дис. ... канд. юрид. наук. Ленинград, 1964. 16 с.

12. Вильнянский С.И. Лекции по советскому гражданскому праву. Харьков : Изд-во Харьковского университета, 1958. Ч. 1. 339 с.

13. Гражданское право : учебник / под ред. : Ю.К. Толстого, А.П. Сергеева. 4-е изд., перераб. и доп. Москва : Велби, 2002. Ч. 1. 722 с.

14. Иоффе О.С. Советское гражданское право : курс лекций. Ленинград : Из-во ЛгУ, 1958. Общая часть. 512 с.

15. Лоренц Д.В. Исковая давность: мировой опыт и перспективы реформы в России. Евразийский юридический журнал. 2013. № 2 (57). С. 120-125.

16. Советское гражданское право : учебник / С.Н. Братусь и др. ; под ред. Д.М. Генкин. Москва : Госюриздат, 1950. Т. 1. 495 с.

17. Ринг М.П. Исковая давность в советском гражданском праве : автореф. дис. ... канд. юрид. наук. Москва, 1952. 18 с.

18. Советское гражданское право. 3-е изд., испр. и доп. Москва : Высшая школа, 1985. Т. 1 / под. ред. О.А. Красавчикова. 544 с.

19. Лебедева К.Ю. Исковая давность в системе гражданско-правовых сроков : дис. ... канд. юрид. наук. Томск, 2003. 243 с.

20. Толстой Ю.К. Содержание и гражданско-правовая защита права собственности в СССР / под ред. О.С. Иоффе. Ленинград : Изд-во ЛГУ, 1955. 219 с. 